\title{
EFEKTIFITAS POSISI PRONASI PADA PASIEN COVID-19 DENGAN GANGGUAN PERNAPASAN TANPA INTUBASI DI RUANG ICU : LITERATUR REVIEW
}

\author{
Effectiveness of Prone Position in Non-Intubated Patients COVID-19 with Respiratory \\ Disease in the ICU: Literature Review
}

\author{
Diah Pujiastuti, Longoday Ireene Natalie Larasasih, Risa Setia Ismandani, Rocky Matius \\ Tenggara, Theresia Bella Purba
}

\author{
STIKES Bethesda Yakkum Yogyakarta
}

\section{Riwayat artikel \\ Diajukan: 12 Agustus 2021 \\ Diterima: 3 September \\ 2021 \\ Penulis Korespondensi: \\ - Diah Pujiastuti \\ - STIKES Bethesda Yakkum Yogyakarta \\ e-mail: \\ diah@stikesbethesda.ac.id}

\section{Kata Kunci:}

COVID-19, Oksigenasi,

Posisi Pronasi

\section{Abstrak}

Pendahuluan : COVID-19 disebabkan oleh virus SARS-Cov-2 yang menyebabkan gejala utama berupa demam, batuk, dada sesak dan dispnea. Penderita COVID-19 yang sakit kritis dan perlu ditransfer ke ICU adalah penderita yang mengalami sakit berat yang ditandai dengan dispnea disertai dengan hipoksemia. Kondisi tersebut sangat memungkinkan penderita mengalami penurunan saturasi oksigen dan kegagalan multi organ2. Posisi pronasi dapat meningkatkan oksigenasi dengan pencapaian $\mathrm{SpO} 2$ ratarata meningkat dari 94\% menjadi 98\%. Tujuan: Penelitian ini dilakukan untuk menganalisis posisi pronasi terhadap peningkatan oksigenasi pasien COVID-19 dengan gangguan pernapasan di ruang ICU yang tidak dilakukan intubasi. Metode: Metode yang dipergunakan adalah tinjauan literature. Pencarian sumber dilakukan melalui google scholar, web PubMed, web Science Direct, web Springer Link, web Biomedcentral dan web Medrxiv. Hasil: Hasil telaah review dari kelima jurnal penelitian menunjukkan bahwa posisi pronasi mampu meningkatkan oksigenasi pada pasien COVID-19 dengan gangguan pernapasan yang tidak dilakukan intubasi. Hasil penelitian dari Solverson, Kevin., et al (2021) mengenai "Tolerability and safety of awake prone positioning COVID-19 patients with severe hypoxemic respiratory failure" menunjukkan hasil yang paling efektif dari posisi pronasi untuk meningkatkan oksigenasi. Kesimpulan: Penggunaan posisi prone pada gangguan pernapasan sedang hingga berat yang dialami pasien COVID-19 dinilai cukup aman untuk dilakukan. Disarankan perawat ruang ICU dapat mengimplementasikan posisi prone pada pasien dengan gangguan pernapasan namun dengan pengawasan secara ketat.

\section{Abstract}

Background: COVID-19 is caused by the SARS-Cov-2 virus which causes the main symptoms of fever, cough, chest tightness and dyspnea. Patients with COVID-19 who are critically ill and need to be transferred to the ICU are patients who experience severe illness characterized by dyspnea accompanied by hypoxemia. This condition allows the patient to experience decreased oxygen saturation and multi-organ failure. Prone position effectiveness to improve oxygenation with $\mathrm{SpO}_{2}$ increase from $94 \%$ to 98\%. Objective: This study was conducted to analyze the pronation position to increase oxygenation of COVID-19 patients with respiratory disorders in the ICU who were not intubated. Method: The method used is a literature review. Source searches were carried out through Google Scholar, PubMed web, Science Direct web, Springer Link web, Biomedcentral web and Medrxiv web. Results: The research showed that the pronation position was able to improve oxygenation in COVID-19 patients with respiratory disorders who were not intubated. Research result from Kevin., et al (2021) about "“Tolerability and safety of awake prone positioning COVID-19 patients with severe hypoxemic respiratory failure" showed the most effective results from the prone position can improve oxygenation. Conclusion:The use of the prone position in moderate to severe respiratory disorders experienced by COVID-19 patients is considered safe enough to do. It is recomended that ICU's nurses can implementation the prone position in patients with respiratory disease but with close supervision. 


\section{PENDAHULUAN}

Keputusan Mentreri Kesehatan Nomor 1778/Menkes/SK/XII/2010 menyebutkan, Intensive Care Unit ICU adalah suatu bagian dari Rumah Sakit yang mandiri (instalasi dibawah direktur pelayanan), dengan staf yang khusus dan perlengkapan yang khusus terapi pasien- pasien yang menderita penyakit, cidera atau penyulit yang mengancam nyawa atau potensial mengancam nyawa. Berdasarkan perkembangannya kebutuhan pelayanan perawatan pasien di ruang ICU semakin meningkat termasuk akibat pandemi COVID-19 yang terjadi di hampir semua negara termasuk Indonesia. COVID-19 disebabkan oleh virus SARS-Cov-2 yang menyebabkan gejala utama berupa demam, batuk, dada sesak dan dispnea. Sampai akhir Juli 2021 telah tercatat 3.331.206 kasus terkonfirmasi positif COVID-19, dan jumlah pasien meninggal dunia sebanyak 90.552 dengan pertambahan 1.893 orang meninggal dalam sehari (Kemenkes RI, 2021). Meskipun sebagian besar penderita mengalami gejala ringan dan bisa sembuh namun sekitar $6,1 \%$ penderita akan menjadi sakit serius dan kritis sehingga membutuhkan perawatan intensif (Marzuki, et al., 2021).

Pada pasien COVID-19 dengan gejala berat salah satunya yang mengalami hipoksemia perlu dilakukan upaya perawatan suportif dan rehabilitatif untuk mengurangi gejala dan risiko kematian. Perawatan suportif yang saat ini sedang banyak dilakukan untuk pasien COVID19 adalah posisi pronasi. Posisi prone akan menyebabkan terjadinya homogenitas dari aleveolar paru, sehingga tidak terjadi hiperinflasi di daerah ventral paru dan kolaps pada bagian dorsal paru. Dengan menggunakan posisi prone rekruitmen oksigen oleh paru pada daerah dorsal meningkat sehingga saturasi oksigen dalam tubuh akan meningkat (Azizah, Garina dan Guntara, 2020).

Literature review tentang efektifitas posisi prone dalam meningkatkan oksigenasi pada pasien COVID-19 yang dirawat di ruang Intensive Care Unit (ICU).

\section{METODE}

Metode yang dipergunakan dalam laporan ini adalah tinjauan literature. Peneliti mendapatkan 122 jurnal sesuai topik yang dipilih dan melakukan screening sesuai dengan kriteria inklusi dan mendapatkan lima jurnal. Kriteria inklusi dalam penelitian ini adalah jurnal sesuai dengan topik yaitu posisi prone, tempat penelitian di ruang ICU, pasien dengan penyakit COVID-19 yang mengalami gejala gangguan pernapasan sedang hingga berat (penurunan saturasi oksigen) dan jurnal tahun 2020 - 2021. Kriteria eksklusi adalah makalah dalam bentuk letter, artikel, diskusi singkat dan korespondensi. Pencarian sumber dilakukan melalui google scholar, web PubMed, web Science Direct, web Springer Link, web Biomedcentral dan web Medrxiv. Kata kunci yang digunakan adalah: posisi prone, saturasi oksigen dan COVID-19. Referensi lain yang digunakan dalam penelitian ini adalah buku perawatan kritis dan COVID-19.

\section{HASIL DAN PEMBAHASAN HASIL}

Pencarian jurnal dilakukan melalui google scholar, web PubMed, web Science Direct, web Springer Link, web Biomedcentral dan web Medrxiv. Pada awal pencarian didapatkan 122 jurnal lalu dilakukan skrining dengan hasil 83 jurnal kemudian 66 jurnal dikeluarkan karena tidak relevan dan memenuhi kualitas, dan yang terakhir 11 jurnal yang tidak menggambarkan kriteria sesuai topik dikeluarkan, 1 jurnal tidak lengkap dikeluarkan, lalu didapatkan 5 jurnal yang memenuhi syarat untuk dilakukan literatur review. Lima jurnal yang terpakai disajikan dalam diagram PRISMA pada Gambar 1

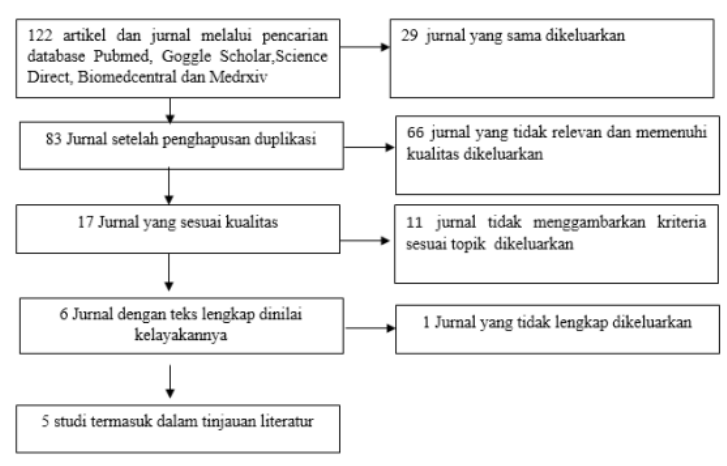

Gambar 1. Diagram PRISMA

Pada penelitian Taboada, et al (2020) peneliti menggunakan studi prospective observasional, peneliti melakukan evaluasi pada pasien yang terkofirmasi positif COVID-19 dan 
mengalami ARDS (Acute Respiratory Disstres Syndrome) baik kondsi sedang ataupun berat. Pasien diinstruksikan pada posisi pronasi hingga pasien mengatakan lelah untuk memperhatakan posisi tersebut. Durasi rata-rata sesi pronasi adalah 10 jam dilalukan sebanyak 16 sesi posisi pronasi selama periode penelitian. Hasil penelitian pada jurnal pertama adalah posisi pronasi meningkatkan oksigenisasi dan kelangsungan hidup pasien COVID-19 dengan ARDS sedang hingga berat.

Jouffroy, et al (2020) melihat dampak dari posisi pronasi pada pasien COVID-19 dengan gangguan pernapasan di Ruang ICU yang tidak diintubasi. Peneliti menggunakan studi observasional retrospektif. Peneliti membagi dalam kelompok, pada kelompok prone positioning berlangsung selama 3 dan 6 jam dilakukan sebanyak 2 kali dalam sehari jika pasien memungkinkan, $\mathrm{FiO} 2, \mathrm{PaO} 2 / \mathrm{FiO} 2$, $\mathrm{PaCO} 2$, dan $\mathrm{pH}$ dilaporkan sebelum sesi proning pertama dan pada akhir sesi proning.

Penelitian Jayakumar, et al (2021) membahas tentang uji coba posisi prone pada pasien COVID-19 dengan pnumonia yang tidak diintubasi. Pasien dibagi menjadi dua kelompok (30 pasien dilakukan posisi pronasi dan 30 pasien dengan posisi telentang. Posisi pronasi dilakukan selama 6 jam dalam sehari dengan durasi per sesi 2 jam. Dari hasil intervensi pada kelompok posisi prone $73 \%$ (22 dari 30 pasien) pasien mampu melakukan posisi prone selama 4 jam lebih per hari. $\mathrm{PaO} 2$ meningkat dari ratarata $73,6 \mathrm{mmHg}$ menjadi $94,9 \mathrm{mmHg}$. Sedangkan pada kelompok kontrol/ kelompok telentang hanya 53\% (16 dari 30 pasien) yang mampu melakukan posisi prone dalam waktu kurang dari 2 jam. Hasil penelitian ini menunjukkan bahwa penggunaan posisi prone aman dilakukan dan berpotensi membantu peningkatan saturasi oksigen.

Penelitian yang dilakukan Solverson, et al (2020) menunjukkan bahawa posisi pronasi dapat dilakukan rata-rata 2 jam dengan durasi 75 menit tiap sesi. Dari 17 pasien 16 diantaranya menggunakan alat bantu napas berupa kanul hidung dan satu pasien menggunakan HFNC. Semua pasien menunjukkan peningkatan oksigenasi dari $91 \%$ menjadi 98\%. Sedangkan Tonelli, et al (2021) menunjukkan bahwa pemberian posisi proning dini efektif digunakan pada pasien yang sadar dan bernapas spontan. Posisi proning dapat meningkatkan $\mathrm{PaO} 2 / \mathrm{FiO} 2$. Pasien yang diberikan posisi proning lebih cepat keluar dari ruang ICU dibanding pasien dengan perawatan standar.

\section{PEMBAHASAN}

Corona virus adalah sekumpulan virus yang menginfeksi sistem pernapasan baik infeksi pernapasan ringan maupun berat seperti pneumonia. Dispnea merupakan gejala yang paling sering timbul pada penyakit berat dan disertai hipoksemia. Progresivitas gagal napas berkembang segera setelah onset dispnea dan hipoksemia. Saat terjadi pneumonia berat atau ARDS alveoli dalam paru-paru meradang dan tersumbat. Kondisi ini menyebabkan pasien mengalami kesulitan bernapas karena paru-paru terisi cairan, menjadi kaku dan sulit mengembang dan mengempis, sehingga pasien membutuhkan pertolongan segera agar terbebas dari keluhan tersebut (Marzuki, 2021). Perawatan suportif rehabilitatif pada pasien COVID-19 dengan gejala berat meliputi latihan pernapasan, modalitas fisik berupa Neuromuscular Electrical Stimulation (NMES) dan pengaturan posisi salah satunya adalah posisi prone untuk meningkatkan saturasi oksigen.

Menurut Caputo, et al (2020) pengaturan posisi prone merupakan manuver yang dapat meningkatkan oksigenasi dengan aman. Mila (2020) dalam menjelaskan posisi prone sangat bagus untuk meningkatkan saturasi oksigen, pengembangan otot dada, pengembangan paru dan dapat menurunkan kejadian apnea. Posisi porne dapat memperbaiki fisiologis pernapasan dan stabilitas kardiovaskuler dengan cara mengurangi kompresi abdomen.

Menurut penelitian Taboada, et al (2020) posisi prone dapat meningkatkan oksigenasi dengan pencapaian $\mathrm{SpO} 2$ rata-rata meningkat dari 94\% menjadi 98\%. Selain itu dalam penelitiannya juga ditemukan adanya peningkatan $\mathrm{PaO}_{2} / \mathrm{FIO}_{2}$ yang sebelumnya 89 menjadi $165 \mathrm{mmHg}$, kondisi ini juga didukung oleh penelitian yang dilakukan oleh Jouffroy, et al (2020). Hal yang sama diungkapkan oleh Solverson, et al (2020) bahwa posisi prone meningkatkan $\mathrm{SpO} 2$ dari 91\% menjadi $98 \%$. 
Posisi prone dapat meningkatkan pertukaran gas melalui penurunan tekanan transpulmonal (perbedaan antara tekanan pembuka jalan napas dan tekanan pleura). Posisi prone menyebabkan berat visera intratoraks dan abdomen dikeluarkan dari dalam paru-paru dan pergerakan diafragma yang terbatas menjadi lega. Posisi prone juga meningkatkan aerasi bagian alveolar yang berventilasi kurang baik, karena bagian dorsal paru-paru yang kaya akan aliran darah yang bergantung pada gravitasi berada pada posisi yang tidak bergantung sehingga pernapasan menjadi lebih baik (Jagan, et al., 2020).

Penelitian Jouffroy, et al (2020) dan Jayakumar, et al (2021) menyatakan posisi prone dilakukan dengan durasi maksimal 6 jam. Berbeda dengan penelitian Tonelli, et al (2020) posisi prone dilakukan selama minimal 3 jam, sedangkan penelitian Solverson, et al (2020) menyatakan pasien rata-rata mampu tolerir terhadap posisi prone selama 75 menit. Penelitian Caputo, et al (2020) durasi pemberian posisi prone pada pasien berbeda-beda tergantung kemampuan pasien dalam mentolerir posisi prone.

Selama pelaksanaan intervensi posisi prone pada beberapa penelitian menyatakan kondisi pasien harus dipantau secara kontinyu. Beberapa hal yang dipantau yaitu laju pernapasan, saturasi oksigen, frekuensi nadi, tekanan darah, tekanan arteri invasif, MAP, serta EKG. Selain itu perlu dimonitor adanya efek samping yang terjadi setelah pasien melakukan prosisi prone. Beberapa pasien mengalami kelelahan pernapasan, takipnea, dan tindakan intubasi pada pasien yang melakukan posisi prone selama lebih dari 16 jam (Taboada, et al., 2020).

Dari lima jurnal yang ditelaah, penelitian mengenai posisi pronasi untuk meningkatkan oksigenasi pada pasien COVID-19 dibuktikan dengan jelas pada penelitian Solverson, et al (2020), penelitian ini dilakukan pada empat rumah sakit dengan jumlah sampel 17 pasien dengan waktu penelitian dilakukan 1 April 2020 hingga 25 Mei 2020. Setiap pasien mendapat perlakuan tindakan posisi pronasi dan supinasi, untuk membandingkan mana posisi yang paling efektif dalam meningkatkan oksigenasi. Penelitian ini memaparkan tahapan-tahapan dari tindakan posisi pronasi pada pasien.

\section{KESIMPULAN}

Kesimpulan dari literatur review penderita COVID-19 memberikan spektrum gejala yang bervariasi mulai dari tanpa gejala, gejala ringan, pneumonia, pneumonia berat, ARDS, hingga syok sepsis. Penggunaan posisi prone pada gangguan pernapasan sedang hingga berat yang dialami pasien COVID-19 dinilai cukup aman untuk dilakukan. Tingkat toleransi pasien terhadap durasi pelaksanaan posisi prone berbeda-beda sehinga selama intervensi perawat perlu melakukan monitoring secara kontinyu kondisi pasien apakah pasien mampu mentoleril aktivitas tersebut.

Berdasarkan hal tersebut maka disarankan perawat yang bertugas di ruang ICU dapat mengimplementasikan pemberian posisi prone pada pasien dengan gangguan pernapasan namun dengan pengawasan secara ketat. Bagi masyarakat umum juga dapat mempraktikkan posisi prone sebagai alternatif untuk mengatasi gangguan pernapasan dalam meningkatkan kemampuan oksigenasi.

\section{DAFTAR PUSTAKA}

Azizah, N, Garina, L \& Guntara, A 2020, 'Scoping Review: Pengaruh Posisi Prone terhadap Saturasi Oksigen $(\mathrm{SpO} 2)$ pada Pasien Covid-19', Jurnal Repository UNISBA. Vol 6 No. 1.

Caputo, Nicholas D., et al, 2020, 'Early Self Proning in Awake, Non Intubated Patients in The Emergency Department A Single E's Experience During The Covid-19 Pandemic', Jurnal Academic Emergency Medicine. Vol 27 No. 5.

Mila, Miranti, 2020, 'Efektifitas Pengaturan Posisi Tidur Dalam Berbagai Posisi (Supinasi, Pronasi dan Side Lying) Secara Midline Terhadap Status Hemodinamik Bayi Prematur Ruang Neonatal Risiko Tinggi RSUP DR. Kariadi Semarang', Jurnal Repository Universitas Muhammadiyah Semarang.

Jagan, Nikhil, et al, 2020, 'The Positioned Study: Prone Positioning in Nonventilated Coronavirus Disease 2019 Patients', Jurnal Critical Care Explorations.

Jayakumar, Devachandran., et al , 2021, 'Standard care vs. awake prone position in adult non-intubated patients with acute 
hypoxaemic respiratory failure secondary to COVID-19 infection - A multi-centre feasibility randomized controlled trial', Journal of Intensive Care Medicine.

Jouffroy, Romain., et al, 2021, 'Impact of prone position in non-intubated spontaneously breathing patients admitted to the ICU for severe acute respiratory failure due to COVID-1', Journal of Critical Care.

Kemenkes RI, 2021, Situasi Terkini Perkembangan Covid-19.

Marzuki, I, 2021, COVID-19: Seribu Satu Wajah, Yayasan Kita Menulis.

Solverson, Kevin., et al, 2021, 'Tolerability and safety of awake prone positioning COVID-19 patients with severe hypoxemic respiratory failure'

Tonelli, Roberto., et.al , 2021, 'Early awake proning in critical and severe COVID-19 patients undergoing noninvasive respiratory support: a retrospective multicenter cohort study' , Jurnal Pulmonology.

Taboada, Manuel., et.al, 2020, 'Effectiveness of Prone Positioning in Nonintubated Intensive Care Unit Patients With Moderate to Severe Acute Respiratory Distress Syndrome by Coronavirus Disease 2019'. 